\title{
Szociális múvészet
}

\author{
A „szociális” jelentése a képzómúvészetben
}

Elöljáróban szeretném rögzíteni, hogy írásom elsősorban szociológiai megközelítését adja annak kérdésnek, amely a múvészeti szcénában az 1990-es évek óta egyre hangsúlyosabban vetôdik fel. A 20. század képzőmúvészetében egyre erôteljesebben, ugyanakkor változó értelemben jelenik meg szociális problematika, amelynek két alapeleme rajzolódik ki a különbözô múvészeti mozgalmak áttekintése során: az egyik az ideológiai-politikai alapállás, a másik a szerzőség kérdése, összefüggésben a múalkotás vagy az esemény létrejöttének folyamatával.

A modern múvészet kialakulásának vizsgálatánál nem lehet figyelmen kívül hagyni a társadalmi-gazdasági közeg radikális megváltozását a 19. században. A nagyipar, a tömegtermelés kialakulása és a technikai fejlődés felgyorsulása nemcsak a világ végleges megváltozásának képzetét keltette, és kedvezett a szociális utópiáknak, hanem ezzel összefüggésben életre hívta a gazdaságosság és a funkcionalitás szempontjainak térnyerését a tudományban és a múvészetekben egyaránt. A fényképezés és sokszorosíthatóság új kihívások elé állította a képzőmúvészetet, mivel a funkció oldaláról kezdte ki. Az élethú és esztétikus kép előállításának új módszerei keletkeztek, s ezzel együtt a polgári igényeket kielégítő múipar és a kapcsolódó giccsgyártás is erôteljes fejlődésnek indult. A képzőmúvészet új útra tért, a múvész sajátos látásmódja és a ,gondolat” fontosabbnak bizonyult, mint a norma. A múvészet fejlődésében mindig fennállt az egyensúly a festészeti hagyomány és a társadalmi közeg között, ezt kívánja - Gombrich metaforikus értelemben használt kifejezése - a „kép ökológiája” (Gombrich-Didier 1999: 72-73.). Az impresszionizmus szakított elsôként a festészeti hagyománnyal, ami nem maradt következmények nélkül. A kubizmus jelentette az igazi törést, amikor már nem a valóság ábrázolása, hanem annak lényegi elemeinek kiemelése történik meg a geometriai formákon keresztül. A forma megváltozása a futurizmusban és a konstruktivizmusban folytatódik, s egyben felel a technikai civilizációra. A gazdaság radikális változásai a technika nagy ívú fejlődése mellett a szociális nyomor különbözô változatait is létrehozták.

A képzőmúvészet ritkán választ direkten „társadalmi” témát. A múvész társadalmi helyzete a 19. század végén a változásoknak kitetté válik; a fizetố megrendelők köre csökken, miközben a közönség kiszélesedik. A múvészek anyagi problémákkal küzdenek, s megrendelő híján azokat festik, akik körülveszik őket a társadalomban. A szociális helyzetek ábrázolása nem jelenti feltétlenül a társadalmi tematika átfogó megjelenését a múvészetben. A szociális irányultság felbukkanása a képzőmúvészetben a szociális utópiák és a szerzôség háttérbe szorulásával bukkan fel, s gyakran összekapcsolódik a közönség aktivizálásával, provokálásával. 
A szociális utópia a képzőmúvészetben a futurizmussal jelent meg, amelynek olasz változata késóbb a fasizmushoz, orosz változata, pedig a bolsevizmushoz csatlakozott. A futurizmus az irodalomban és a vizuális múvészetekben egyaránt jelen volt; a múlt harcias tagadása, a jövőbe és a technikai fejlődésbe vetett hit, mozgás, lendület, dinamizmus jellemezte az irányzatot. A múvészetben megjelent valami, ami addig nem volt; az individuum másodlagossága, minden egyéni kreativitás összeolvadása az „összmúvészetben”. A szociális tematika a futurizmusból kinövő, vagy azzal szorosan összefüggő konstruktivizmust, szuprematizmust áthatotta, majd a későbbi kapcsolódó építészeti irányzatokat is, amilyen a De Stijl mozgalom és a Bauhaus. A konstruktivizmus, s egyúttal a kelet-európai avantgárd kezdetét jelző demonstratív dátum az 1913-as év, amelyben Malevics Fekete négyzete megszületett. A konstruktivizmusban s annak végletekig vitt formájában, a szuprematizmusban a geometriai mozzanat túnik a legfontosabbnak, a gondolat azonban ez esetben a formánál lényegesebb. A szuprematizmus három szimbólumot használ; a négyzetet, a keresztet és a kört. Ezek a formák azonban nem a kubizmusból egyszerúsödött formák - ahogy Perneczky Géza írja - hanem az orosz társadalomban nagyon is érthető szimbólumok. „A kubizmus hatása fontos volt, de míg Picasso vagy Braque a geometriai tér- és formaábrázoló eszközként használta, addig a szuprematizmusban a négyzet nem eszköz többé, hanem cél, tartalom, abszolútum." (Perneczky 1988: 64.) Malevics a négyzet, Liszickij a kör, majd gömbforma jelentéstartalmát fogalmazta meg proun-kompozicióiban. Az orosz avantgárd félig ikonszerú, félig forradalmi alakzataiban az abszolútum, a misztikum és a hagyományos tolsztojiánus felfogás ötvöződik az új természettudományos ismeretek által keltett képzetekkel. A múvészeket a jövő társadalmának víziójának megragadása foglalkoztatja képeikben, építészeti terveikben egyaránt. A múvészet által megvalósított társadalmi utópia az avantgárd általános vonása, de a kelet-európaiban a társadalmin van a hangsúly hagyományosan. A szociális utópia jól illeszkedett az avantgárd intellektualizmusához, vegyítve a dekonstrukciót a konstruktivizmussal. A hagyományosan messianisztikus kelet-európai értelmiség az emigrációban is nehezen viselte a nyugati társadalmak szekularizálódott múvészetének iparszerú szakmaiságát. A kelet-európai avantgárddal a szociális utópia egyszer és mindenkorra beköltözött a múvészetbe. Ezek a víziók az emigrált múvészek közvetítésével jutnak át Németországba, és hatják át a Bauhaust.

A társadalmi tematika korabeli másik megjelenési formája a holland De Stijl mozgalom és a már említett Bauhaus. A holland képzőmúvészeti és építészeti csoporthoz tartozott Piet Mondrian és Theo van Doesburg, Naum Gabo, hogy csak néhány lényeges alakot említsek a számos múvész közül. 1917-ben folyóiratot alapítottak, amelyben társadalmi és gazdasági problémákat fogalmaztak meg, amelyet a múvészetben geometriai formákkal ábrázoltak. Nemcsak festészettel és építészettel, hanem lakberendezési tárgyak készítésével és textiltervezéssel is foglalkoztak. Folyóiratukban bemutatták az orosz konstruktivistákat, az olasz futuristákat és a dadaistákat egyaránt. A magyar Huszár Vilmos is tagja volt a csoportnak, s közvetítette késóbb Kassák Ma címú lapja felé a holland csoport elveit. A De Stijl a Bauhausszal is kapcsolatba került, de a kapcsolat nem vált szorossá. 
A Bauhaus 1919-ben jött létre Walter Gropius kinevezésével a weimari iparmúvészeti főiskola élére, aki termékeny múvészeti közösséget hozott létre az iskolában sajátos oktatási programmal. A Bauhaus praktikus megoldásokat keresett a mútermi múvészet elszigeteltségének régi problémáira. Az iskola növendékeinek, akik eleinte kizárólag festők voltak, meg kellett tanulniuk egy kézmúves mesterséget, és segédvizsgát kellett tenniük. Az iskolában asztalos-, fém-, szövő-, színpadi, nyomdai és kőfaragó múhelyek közül választhattak a növendékek, csak ezután kezdődhetett az építészeti oktatás. A kísérleti és modellkészítő múhelyekben, amelyek az alapmúhelyekkel szoros összhangban dolgoztak, olyan - többnyire lakberendezési - tárgyakat készítettek, amelyeket már megtervezésükkor ipari előállításra szántak, ezek elérhető anyagokból készültek, funkcionálisak, esztétikusak és a piac felvevőképességéhez alkalmazkodók voltak. A modelleket a megfelelő iparágaknak eladták, s a licencdíjakból befolyó összeget a múhelyek fejlesztésére és a diákokra költötték. Nemcsak tárgyak, hanem épületmodellek is készültek, amelyek közül viszonylag kevés valósult meg. A Bauhaus a termelés szelleméhez igazított életmódot kívánt kialakítani mind az építészetben, mind a lakberendezésben. A legfőbb szempontok: a termelékenység fokozása s az anyag megfelelő megmunkálásával létrejövő intenzív hatás, valamint a funkcionalitás voltak (Moholy-Nagy 2010: 92-95.). (A házakat előre legyártott elemekből tervezték, amelyeket raktárban tárolták, így a házak az addigi habarcsos módszerek helyett napok alatt összeállíthatóak lettek - a tervek szerint.) A Bauhaus magyar képviselői (Molnár Farkas, Weininger Andor, Breuer Marcell, Stefán Henrik, Forbát Alfréd stb.) szinte mindannyian megfordultak a Gropius-iskolában. 1921 után az ideiglenesen kikiáltott Baranya-Bajai Szerb-Magyar Köztársaságon belül a pécsi iskola a magyar Bauhaus fontos székhelye volt, élén Dobrovics Péter festővel. A megye Magyarországhoz történő visszacsatolása után a múvészek nagy része emigrált (Várkonyi 2010: 70.).

A Bauhaus úgy viszonyult a konstruktivizmushoz, mint a gyakorlat az elmélethez. Az orosz konstruktivisták nem csak a holland De Stijl mozgalommal, hanem a Bauhausszal is intenzív kapcsolatot ápoltak, legalábbis az első időszakban. Míg azonban az orosz avantgárd ,idea-múvészet” volt (Perneczky 1988: 62.), a rá jellemző kelet-európai messianizmussal, a német iskola a nyugati társadalom szakszerú múhelye, amelytôl nemhogy nem idegen a múvészet nagyipari termelése, hanem programszerú lényeges eleme.

A szociális alapokra helyezett múvészet újabb fázisa a kelet-európai országokban a szocialista realizmus lett, amelyet leplezetlenül „közösségi múvészetnek” neveztek, kifejezve annak szándékolt irányát. A közösségi alatt a kommunista ideológia és hatalom által diktált értékrendet és tematikát értették, összekapcsolva a köz által érthetô realizmussal. A realizmus célja a mondanivaló félreérthetetlensége volt, s ezt a célt semmiféle absztrakt forma nem szolgálta volna elég jól. A keleteurópai szocialista országokra jellemző, a hatalom és az ideológia által megkövetelt tartalmak szocialista realizmus formájában történő kifejeződése a két háború közti orosz (és hazai) avantgárd szerves folytatásának túnik, de ez csak a politikai irányultság szülte látszat. Valójában a kettőnek nincs köze egymáshoz a formavilág tekintetében. Természetesen a sztálini idők képzőmúvészeti termékeiben már meg- 
jelent ez az utópista realista ábrázolási mód, de nem az avantgárdban, ahogy más érintett országokban sem az avantgárd az előzménye. A tartalom talán közös, de a forma mássága mély különbségeket eredményez a két irányzat között. A szocialista realista ábrázolások új közösségnek és új közönségnek szólnak, s bennük a múvészet valóságot visszatükröző funkciója jut érvényre. Ennek jegyében „Közösségi múvészet felé” címmel nyílt kiállítás Budapesten 1948-ban. Ugyanezt a címet viseli harminc év múlva Kepes György könyve (Kepes 1978), amelyben a szerző a közösségi múvészet alatt nem csupán a munkás, paraszt, partizán, áldozat, dolgozó nő tematikájú képeket és szobrokat érti, hanem - reagálva a Nyugaton honos irányzatokra - a környezettel, a természettel harmóniában élő múvészetet (is).

A szocialista országokban sokáig, gyakorlatilag az 1970-es évek közepéig töretlen szocreál képzőmúvészetében a szociális utópia vonásai megjelennek ugyan, de a század eleji avantgárd stílus jegyei nélkül. Sokkal inkább a használhatóság, a gyakorlatiasság és a funkcionalizmus elveit érvényesítik, mint a konstruktivizmus totalitás ideáját. A szocializmusban épített házgyári elemekből készült lakótelepek alig hasonlítanak a Bauhaus építészeti modelljeire, bár a távoli rokonság felismerhetô.

A kelet-európai avantgárd kezdeteit, különösen Malevics munkáit (Fekete négyzet, 1913; Vörös négyzet, 1914) előszeretettel állítják párhuzamba Duchamp readymade-jeivel (Biciklikerék, 1913; Gyógyszertár, 1914; Fésú, 1916; Forrás, 1917), mintha ugyanaz a dolog kezdődött volna el egyszerre Európa keleti és nyugati felén. Természetesen Duchamp provokatív kérdésfelvetését a múvészet mibenlétével kapcsolatban nem lehet eléggé méltányolni a 20. század képzőmúvészetének folyamatos változása szemszögéből nézve, egyet azonban semmiképpen nem állíthatunk; hogy ez a múvészi gesztus ugyanaz volna, mint Malevicsé. A szociális tematika értelmezése teljesen más a két múvésznél, s míg Malevicsé idea-múvészet, addig Duchamp a szociális múvészet fogalmához inkább a múvészi individuum, a szerző eltüntetésének gesztusát adja, mintsem bármi mást. A nyugat-európai képzőmúvészetben talán nem túlzás azt állítani, hogy sokkal inkább a szerző negligálása, majd az 1960-as évektől a közönség provokatív aktivizálása jelentette elsősorban a múvészet szociális vonatkozását egészen az 1970-es évek végéig. A keleteurópai eredetú szociális utópiák mintázata is fel-felbukkan politikai indíttatású, baloldali gondolatként ezekben a mozgalmakban, amelyek között mindenképpen meg kell említeni az informel irányzathoz tartozó CoBrA csoport és a Szituacionista Internacionálé szociális felfogását.

1948-ban jött létre Párizsban a CoBrA csoport (a név három város betúiből képzett: Koppenhága, Brüsszel, Amszterdam). Néhány éves múködésük alatt résztvevő múvészek (Karel Appel, Asger Jorn, Christian Dotremont, Joseph Noiret stb.) a forma és a színek szabadságát vallották, az alkotást spontán és kísérleti folyamatnak tekintették. Nézeteikben a marxizmushoz közel álltak, hasonlóan a Lettrista Internacionáléhoz, amelyben szintén az a Guy Debord játszott vezető szerepet, aki 1957-ben a Szituacionista Internacionálét megalapította. A Szituacionista Internacionálé proletárforradalmat hirdetett, s ennek előkészítésére alkalmazták kedvenc felforgató technikáikat: a szituációk megteremtését és a détournement-t, az eltérí- 
tést. A détournement-nak Debord két fajtáját különíti el. A kisebb elemek (egy újságkivágás, egy felvétel stb.) attól nyerik el jelentőségüket, hogy milyen kontextusban fordulnak elő. A másik típus a megtévesztő détournement, politikai, filozófiai vagy irodalmi szöveg, amelyet más jelentéssel ruház fel az új szituáció, amelyben megjelenik (Debord-Wolman 1956). A szituacionisták jelentős szerepet játszottak jelszavaikkal az 1968-as diáklázadás előkészítésében is. Debord nevéhez fűződik a spektákulum fogalma, amely a társadalmi viszonyok átfogó, ugyanakkor rendkívül árnyalt kategóriája. ,A spektákulum a fejlődésnek az a foka, amikor az áru bevégzi a társadalmi lét teljes leigázását. Nem pusztán arról van szó, hogy az áruhoz fúződő viszony mostantól láthatóvá lesz - de ez lesz az egyedüli látható dolog: a világ, amely a szemünk elé tárul, az áru világa." (Debord 2006: 25-26.)

A mozgalom legfontosabb dokumentumai a folyóiratok voltak, amelyek a csoport nevének rövidítését (IS) viselték címükben. A csoport múvészeti teljesítménye nem jelentős, sokkal inkább Debord zseniális, máig helytálló gondolatai (Erhardt 2006: 143.), s az a körülmény, hogy sok, máig eleven köztéri formát (pl. graffiti, gerillapropaganda stb.) megelőlegeztek.

Az 1960-as években induló fluxus, maga az áramló figyelem, a múvészet és az élet összekapcsolódása, és a fluxussal jelent meg a humor a múvészetben (Böhringer 2006: 19-21.). A fluxus természeténél fogva a hagyományos múvészeti elképzelések anyagisága ellen fordult, mégsem dolgozott ki olyan múvészetfogalmat, amely lehetővé teszi mindenki számára, hogy múvész legyen. A fluxus eljutott a kollektív munkához és a személytelenséghez, az antimúvészethez és a provokációhoz. Mindezek az elemek azonban inkább a közösen végzett, a múvészeti közösségi munkához, semmint a szociális teóriákhoz vitték közelebb ezt az igen nagy hatású irányzatot, bár Maciunas, akinek a nevéhez füződik a mozgalom elindítása, gyakorlatilag kommunista volt. A fluxus összmúvészeti törekvései összekapcsolták a performanszt, happeninget, mindenféle múvészeti akciót az írott múvészet sajátos, új formáival. Az első Herman de Vries periodikája volt Integration címmel, 1963-ban George Brecht VTRE címmel indított folyóiratot, melyet Maciunas különbözóképpen formált át; ccVTRE, ccValise TRANGLE stb., majd 1964-től megjelentette híres FLUXKIT és FLUX YEAR BOX dobozait. A dobozolás ötlete Brechttől származott, aki viszont Duchamp-tól leste el, de Warhol is dobozolt. Mindez jól példázza a szerzőség összemosódását az új formák kitalálásában. 1965-ben Ben Vautier Tout címmel kézzel gyártott lapot adott ki, amelynek előzménye az informelhez kapcsolódó képzőmúvészek párizsi kiadványa $K W Y$, amelyben eredeti munkákat füztek össze lappá. A fluxussal majdnem egyidőben jelentkezett a mail art, amely a fluxushoz hasonló elven múködött (Perneczky 1990: 31-32.). A mail art létrehozott egy stabil múvészeti hálót azokból a múvészekből, akik a múvészeti világ üzleties jellegét nem fogadták el, vagy abban nem tudtak részt venni. Az 1960-as években egy sereg múvészeti áramlat indult el, nagyrészt egymással átfedésben, s szinte egymással felcserélhetők voltak. Az avantgárd nagyjából 1967-ben, a koncept megjelenésével fordult át valami mássá. Az 1970-es években indult el az avantgárdból való tömeges emigráció, eddig tartott az a szakasz, amely egyben egy redukciós folyamat végét is jelenti. Perneczky az 1968-as 
májusi eseményektől eredezteti az avantgárd végét és egy új, második nyilvánosság korszakának kezdetét. Ez a második nyilvánosság nem jöhetett volna létre a modern médiumok és a sokszorosító technikák nélkül, ahogy korábban az avantgárdnak nem is álltak ilyen eszközök a rendelkezésére. Ez a kívül maradás azért jött létre, mert az elit múvészet nyilvánossága nem adott helyet a fiatalabb generációk kísérletezőkedvének a galériákban. Ennek az elkülönülésnek az időszaka nagyjából 1988-ig tart, s ami utána következik, az a komputerkorszak, a webdesign és a számítógépes grafika világa (Perneczky 1990: 10., 219.).

A holland származású Joseph Beuys első munkái az 1950-es években jelentek meg, később részt vett a fluxus mozgalomban, majd kivált belőle. Az 1970-es években fejtette ki a „,szociális plasztikával” kapcsolatos nézeteit, s nagy múvészi sikerei is ehhez a tematikához kötődtek. Beuys a társadalmat tekintette szobornak, amelyen mindannyian munkálkodunk, ennélfogva mindenki lehet múvész, és minden múvészet. Egy sajátos szociális utópiát hozott létre, amelynek kimunkálásán és gyakorlati megvalósításán évtizedeken át dolgozott. Ennek az utópiának az elvi alapját a Rudolf Steiner által létrehozott antropozófia alkotta. A szellemi szabadság, a közvetlen demokrácia és a marxizmust elutasító szocializmus-felfogáson alapult steineri alapokon - a beuysi szociális utópia. (Harlan-Rappmann-Schata 2003: 13-15.). A közvetlen demokráciát, a pártok nélküli kormányzást olyan komolyan vette, hogy Az általa létrehozott szabadiskolában igyekezett átadni eszméit, amelynek szerves részét képezte a múvészet, amelynek elsősorban terápiás funkciót tulajdonított. „Mi egy demokratikus szocializmushoz akarunk eljutni (...) Tehát valami újat akarunk - olyasmit akarunk kínálni, amely alkalmas mind a nyugati magánkapitalizmus, mind a keleti államkapitalizmus meghaladására" (Harlan-RappmannSchata 2003: 26.) - mondta 1973-ban Beuys nagyszabású, ideológiai értelemben sokoldalúan kidolgozott szociális utópiájában, a cselekvésre is nagy hangsúlyt fektetett, és nemcsak politikai értelemben. A legnagyobb forradalmi erőnek a múvészetet tartotta, mert az emberi viszonyok csak az emberi kreativitás következtében tudnak megváltozni. A múvészet és az élet egy, a múvészetből az életbe visszaáramló elemek átalakíthatják a társadalmat. „Magasabb szinten kell helyreállítani a kapcsolatot az istenekkel és a mítoszok szövevényével (...) A múvészet az érzékfeletti szférából hoz le valamit, ami megváltoztatja a viszonyokat." (HarlanRappmann-Schata 2003: 47., 56.)

A szociális plasztika lényege, hogy maga a társadalom a múalkotás. Minden ember lehet múvész, ha elképzelései vannak a szociális organizmusról, és az elidegenedést kreativitássá alakítja. A hideg és a meleg a világ alaperői (nem csak fizikai értelemben), két pólust alkotnak, és egy nagyon összetett energiával függenek össze. Ebben az összefüggésben tartja az elidegenedést hideg plasztikának, a hő plasztikát szeretetnek. A zsír, a méz és a viasz azok az anyagok, amelyek a hôhatásokra rendkívül jól reagálnak, és szerves vonatkozásaik vannak. Beuys szociális plasztikája az utolsó átfogó társadalmi utópia, melyet a 20. század képzőmúvészetében tapasztalhatunk. Utána már csak kísérleteket láthatunk, amelyeknek szociális vonatkozásai is vannak, de mégis elsősorban a múvészet megújítását célozzák. 
Az avantgárd elmúltával a társadalmi tematika a múvészet cinikus önigenlésének sajátos termékévé válik, amely karöltve jár a határokat feloldó „mindenki múvész” és „minden lehet múvészet” közhelyeivel. A nagyipar lassan magát a múvészetet is múiparrá alakította át. Böhringer szerint ez annyit jelent, hogy a nemzetközivé vált múvészeti képző, termelő, közintézményi és piaci hálózat belső autonómiával bír, és maga határozza meg mibenlétét és teendőit, s azt is, hogy mi a múvészet. „Amit múvészetként érzékel, termel, és teoretikusan újratermel - az a múvészet. Ez az ipar megengedheti magának a vitákat, össze nem illó és egymással polemizáló meghatározásokat. Ebben rejlik az ereje.” (Böhringer 1995: 17.) Az avantgárd még nem volt nagyipari, a késóbb kialakult új formák egy része sem szolgált rá a múipari jelzőre, legalábbis addig, ameddig frissességet vittek a múvészetbe. Ezek a mozgalmak általában kívül maradtak a nagy nemzetközi piacon, intézményeken, illetve amikor bekerültek, szinte azonnal ki is múltak.

Az 1990-es évektől a múvészetben bekövetkezett az úgynevezett ,,szociális fordulat". Megszúnt a politikai és az esztétikai radikalizmus összekapcsolódása, és az utópia tere maga a szociális tér lesz. A múvek nyíltan a társadalmi jelenségekkel, a közösséggel foglalkoznak, és az erről való diskurzusok száma megnövekszik. A társadalmi gyakorlatok által létrehozott interszubjektív tér kerül a múvészeti vizsgálódások középpontjába. Számos név alatt futnak ezek szociális gyakorlatok: társadalmilag elkötelezett múvészet (socially engaged art), közösségen alapuló múvészet (community-based art), köztéri múvészet (public art), határ-múvészet (littoral art), részvételen alapuló (participatory), kollaboratív múvészet (collaborative art), beavatkozáson (interventionist), kutatáson alapuló (research-based) stb. Az új formák által létrehozott múvek, gyakorlatok, események nem piacképesek, nem is kívánnak azok lenni, sőt gyakran nem is nevezhetők múvészetnek, így értékelésük során gyakran inkább etikai, mintsem esztétikai kategóriák alkalmazhatók. A múvészet demokratizálódása elvileg kinyitotta az alkotó múvészet kapuit mindenki előtt, de gyakorlatilag az, hogy egy alkotási folyamat végén megjelenő tárgy vagy esemény esztétikai minőségú lesz-e, az nem a jó szándék kérdése. A társadalmi együttmúködésen alapuló múvészet esztétikai kategóriái nem kidolgozottak, ennek következtében sokkal inkább fókuszál a múkritika az együttmúködés hogyanjára (Bishop 2006: 8.). A végeredményről a folyamatra helyeződik át a hangsúly, és fontossá válik, hogy a múvész szerepe meddig terjed az aktív közönséggel való együttmúködésben, meddig viseli az esztétika bélyegét a mú, és mikor tekinthető pusztán kollaborációs folyamatnak vagy párbeszédnek. Ezek a relációs gyakorlatok gyakran a múvészetet csupán eszközül használják a társadalmi kapcsolatok létrehozásában vagy megerôsítésében, de az is előfordul, hogy a múvész az együttmúködés helyett inkább uralja a helyzetet, ami viszont etikai problémákat vet fel a közös alkotás szempontjából. A múvészet aktivizmussá vagy terápiás folyamattá válása a szerzőség feladása során már nemcsak az esztétikai szempont eltúnésének a problémáját veti fel, hanem a felelősségét is. 


\section{Hivatkozott irodalom}

Bishop, ClaiRE (2006): A szociális fordulat: A kollaboráció és elégedetlenei [The Social Turn, Artfórum, 2006. február]. http://exindex.hu/index.php?l=hu\& page $=3 \&$ id $=531$

BöHRINGER, HANNes (1995): Kísérletek és tévelygések. Budapest, Balassi-BAE Tartóshullám.

BöHringer, HANNes (2006 [1993]): Szinte semmi. Budapest, Balassi Kiadó-BAE Tartóshullám.

DeBord, Guy (2006 [1992]: A spektákulum társadalma, Budapest, Balassi-BAE Tartóshullám, 141-156.

Debord, Guy-Wolman, Gil (1956): A User's Guide to Détournement. Internet: www.bopsecrets.org/SI/detourn.htm

GOMBrich, ERNST-ERIBOn, Didier (1999 [1991]): Miról szólnak a képek? Budapest, Balassi-BAE Tartóshullám.

Harlan, Volker-Rappmann, Rainer-Schata, Peter (2003 [1984]): Szociális plasztika. Anyagok Joseph Beuyshoz. Budapest, Balassi.

KePES GyöRgy (1978): A közösségi múvészet felé. Budapest, Magvető.

Moholy-NAGy LÁszló (2010 [1925]): Előtörténet. A Bauhaus megalapítása. In Bajkay Éva (szerk.): A múvészettól az életig. Magyarok a Bauhaus-ban. Budapest, Hungarofest-Janus Pannonius Múzeum, 92-95.

PerneCZKy GÉZA (1988): A korszak, mint múalkotás. Budapest, Corvina.

PERNECZKY GÉZA (1990): A háló. Alternatív múvészeti áramlatok a folyóirat-kiadványaik tükrében 1968-1988. Budapest, Héttorony.

VÁRKONYI GYÖRGY (2010): „Elötanfolyamok”. Budapest-Pécs-Weimar. In Bajkay Éva (szerk.): A mûvészettôl az életig. Magyarok a Bauhaus-ban. Budapest, Hungarofest-Janus Pannonius Múzeum, 66-91. 